\title{
Cysteine Proteinase
}

National Cancer Institute

\section{Source}

National Cancer Institute. Cysteine Proteinase. NCI Thesaurus. Code C16481.

An enzyme that contains an unpaired cysteine in the active site which acts as a

nucleophilic thiol to catalyze the proteolytic processing of other proteins or polypeptides. 